\title{
Implementasi Penggunaan Kitab Matnu Al-Ajurumiyyah Pada Madrasah Tsanawiyah
}

\section{Titin Fatimah, Muh. Paris Fauzi, Atna Akhiryani}

Institut Agama Islam Negeri Palu, Indonesia

Jl. Diponegoro No. 23, Kec: Palu Barat, Kota Palu, Sulawesi Tengah, 94221, Indonesia

Corresponding E-mail: atna.nn90@gmail.com

\begin{abstract}
This research aims at providing a clear description about the implementation, the obstacle and the technique solution of the use of Mat'nu Al-Ajurumiyyah book to the students at Raudhatul Musthafa Lil Khairaat Islamic Boarding School Palu in Arabic learning. This research employed descriptive qualitative method. The result of this research showed that Arabic learning is one of featured subjects at Raudhatul Musthafa Lil Khairaat Islamic Boarding School Palu. This is because Arabic subject is required to understand Al Qur'an and Al Sunnah.
\end{abstract}

Keywords: kitab, ajurumiyah.

\begin{abstract}
Abstrak
Penelitian ini bertujuan untuk mengetahui bagaimana impelentasi penggunaan kitab Mat'nu Al-Ajurumiyyah untuk santri di Pondok Pesantren Raudhatul Musthafa Lil Khairaat kota Palu dan kendala serta solusi teknik penggunaan kitab Matnu AlAjurumiyah dalam pembelajaran bahasa Arab untuk santri di Pondok Pesantren Raudhtaul Musthafa Lil khairaat kota Palu. Metode penelitian yang digunakan adalah pendekatan kualitatif deskriptif. Hasil penelitian ini menunjukkan pembelajaran bahasa Arab merupakan salah satu mata pelajaran unggulan di Pondok Pesantren tersebut. Hal ini karena pelajaran bahasa Arab merupakan salah satu ilmu yang harus diketahui seseorang yang ingin memahami Al Qur'an dan Al Sunnah.
\end{abstract}

Kata Kunci: kitab, ajurumiyah.

\section{PENDAHULUAN}

Laju pertumbuhan dalam dunia pendidikan dewasa ini banyak mengalami kemajuan dan perubahan, perubahan ini mengarah kepada perbaikan dan pengembangan di berbagai bidang. Tidak terkecuali dalam bidang Pendidikan Bahasa Arab khususnya di Pondok Pesantren Raudhatul Musthafa lil Khairaat yang pada proses pembelajarannya banyak menggunakan kitab-kitab berbahasa Arab (kitab kuning).

Dengan demikian untuk memahami bahasa Arab itu sendiri perlu di pelajari hal-hal yang mendasar dalam bahasa Arab itu sendiri khususnya kaidah-kaidah bahasa Arab. Selain itu bahasa Arab juga di gunakan untuk memenuhi kebutuhan seorang muslim dalam melakukan ibadah shalat, untuk memenuhi kebutuhan ini, 
bahasa Arab pada mulanya di ajarkan dengan metode verbalistik (alphabetic metode). Seiring dengan perkembangan zaman, metode verbal dianggap sudah tidak cocok dan tidak cukup, hal ini karena pembelajaran bahasa Arab tidak hanya sekedar membaca Al-Qur'an yang di pakai sebagai sarana peribadatan. Melainkan berkembang sebagai Al-Qur'an sebagai pedoman hidup yang harus dipahami dan diamalkan ajarannya. Demikian pula do'a atau bacaan dalam shalat yang sangat perlu dipahami dan dihayati maknanya, agar shalat benar-benar berfungsi sebagai media komunuikasi dengan sang pencipta.

\section{Pondok Pesantren Raudhatul} Musthafa Lil Khairaat merupakan Pondok yang merujuk pada bidang salafiyah dan tidak belajar dengan ilmu lain kecuali ilmu agama, Pondok tersebut memiliki ruas kebutuhan yang ada, disitulah santri di didik dengan ilmu agama salah satunya yaitu bahasa Arab dan mempelajari kitab kuning. Laju pertumbuhan tersebut Pondok tersebut sudah melebar luas, sehingga mempunyai cabang-cabang tersebut. Dan inilah alasan yang sangat mendasar untuk penulis dalam melakukan penelitian tersebut, karena belum ada salah satu orang pun yang meneliti di Pondok tersebut, maka penulis berinisiatif untuk melakukan penelitian tersebut unruk mengembangkan bahasa Arab ke depan khususnya di dalam mempelajari kitab Mat'nu Al-ajurumiyyah. Dan untuk mempelajari kitab tersebut di butuhkan adanya metode agar bisa dipahami.

Selanjutnya untuk memenuhi tuntutan ini, maka kemudian muncullah metode gramatika tarjamah, pengajaran bahasa Arab dalam bentuk ini adalah yang paling dominan di tanah air, kontribusinya dalam memahamkan umat Islam yang berada di Indonesia terhadap ajaran agama Islam yang sangat besar, meskipun pada saat ini Indonesia adalah agama Islam yang sangat besar dan pada saat ini telah banyak ditemukan metode pengajaran bahasa Arab yang lain, namun metode ini masih banyak dipakai dan diper tahankan eksitensinya oleh banyak lembaga pendidikan agama Islam antara lain yaitu di Pondook Pesantren Raudhatul Musthafa Lil khairaat, sebagai suatu lembaga yang dulunya hanya di pandang sebelah mata, pada saat ini mulai mendapat perhatian yang serius baik di kalangan pemerintah maupun masyarakat. 
Untuk mewujudkan tercapainya tujuan pendidikan maka santri harus mampu menciptakan suasana belajar yang kondusif sesuai dengan kebutuhan santri dan harus mampu meningkatkan efektivitas belajar mengajar seperti yang terlihat di lapangan bahwa tidak jarang dijumpai santri berminat dalam pelajaran bahasa Arab, baik sekolah dasar maupun tingkat lanjutan.

Hal ini di sebabkan karena mereka menganggap pelajaran bahasa Arab adalah bahasa yang sangat sulit dan membosankan. Akibatnya setiap pokok bahasa yang mereka jumpai sulit untuk dipahami oleh peserta didik. Sehubungan dengan pengertian tersebut sangat baik bagi guru (pendidik) untuk memilih berbagai metode ataupun teknik pembelajaran yang sesuai dengan pokok pembahasan yang akan di sampaikan, agar peserta didik tidak merasa jenuh. Sehingga konsep yang akan ditanamkan melekat pada diri anak. Kesemuanya itu tidak terlepas dari metode dan teknik yang harus digunakan pendidik khusunya pada mata pelajaran bahasa Arab.

Alasan yang mendasari pelaksanaan penelitian ini yaitu untuk mengetahui pelajaran bahasa Arab dengan teknik penggunaan kitab Mat'nu Alajurumiyyah dalam pembelajaran bahasa Arab. Teknik penggunaan kitab khususnya kitab Mat'nu Al-ajurumiyyah dalam pembelajaran bahasa Arab. Serta kelemahan atau kelebihan dari teknik ini. Serta faktor-faktor pendukung pembelajaran yang dapat di jadikan sebagai tolak ukur untuk mengoptimalkan penerapan teknik penggunaan kitab Mat'nu Al-ajurumiyyah dalam pembelajaran ilmu Nahwu sehingga dalam proses pembelajaran akan lebih baik dan efektif.

Berdasarkan latar belakang yang telah diuraikan di atas, maka penulis menarik sebuah pokok masalah, yakni: (a) Bagaimana Implementasi penggunaan kitab Mat'nu Al-ajurumiyyah untuk santri di Pondok Pesantren Raudhatul Musthafa Lil Khairaat kota Palu? (b) Apa kendala serta solusi teknik penggunaan kitab Mat'nu Al-ajurumiyah dalam pembelajaran bahasa Arab untuk santri di Pondok Pesantren Raudhtaul Musthafa Lil khairaat kota Palu?

Biografi Singkat Pengarang Kitab Mat'nu Al-Ajurumiyyah serta penjelasannya 
Kitab Mat'nu Al-ajurumiyyah merupakan kitab dasar dalam ilmu nahwu, karangan Abu Abdillah Muhammad bin Muhammad bin Dawud Ash Shinhaji (kadang disebut Ash Shonhaji) ${ }^{1}$ yang lebih dikenal dengan nama Ibnu Ajurum. AlAjurum merupakan bahasa barbar yang berarti orang yang meninggalkan kemewahan dan memilih laku sufi (Al Faqir Ash shufy). Ibnu Ajurum rahimahullah dilahirkan di kota Fas, sebuah daerah yang besar di Negeri Maghrib ( Maroko) pada tahun 672 H.. ${ }^{2}$ Ibnu ajurum rahimahullahu wafat di kota Fas, pada hari senin, tanggal 30 shafar 723 $\mathrm{H}$.

Ibnu Ajurum rahimahullah menyusun kitab Mat'nu Al-ajrumiyyah pada tahun 719H/1319M sekitar empat tahun sebelum beliau wafat. Adapun dalam kitab Mat'nu Al-ajurumiyyah tersebut berjumlah 27 bab.

\section{Metode gramatika tarjamah dalam pembelajaran Nahwu (Mat'nu Al- ajurumiyyah)}

Metode gramatika dan terjemah adalah sebuah metode pembelajaran

\footnotetext{
${ }^{1}$ Seorang kyai., Biografi imam ibnu ajjurum pengarang kitab "jurumiyah" (on line), (https://blogspot.com), diakses pada tanggal 18 september 2020.

2 ibid
}

bahasa Arab yang dalam prosesnya mengajarkan kaidah-kaidah tata bahasa dan kosakata untuk memahami teks bahasa Arab. Dalam aplikasinya metode ini menggunakan bahsasa peserta didik sebagai bahasa pengantar, misalnya bila metode ini diterapkan disebuah sekolah yang peserta didiknya orang Indonesia maka bahasa pengantarnya yang digunakan oleh guru dalam mengajarkan bahasa arab adalah bahasa Indonesia. ${ }^{3}$

Metode ini dianggap sebagai metode tertua dalam pembelajaran bahasa Arab dan dianggap mempu mengembalikan masa kebangkitan negaranegara islam, karena menyalin peninggalan peradaban manusia dari bahasa-bahasa yunani dan latin ke dalam bahasa Arab, sebab banyaknya keterkaitan antara negara-negara Eropa Islam, sehingga penduduknya merasa perlu untuk mempelajari bahasa ini. Mereka serius mempelajari dan mengajarkan bahasa Arab. Hal ini terus berlangsung sampai pada abad pertengahan. Metode yang digunakan dalam pembelajaran bahasa Arab ini adalah menjelaskan kaidah bahasa

\footnotetext{
Fathur Rohman, metodologi pembelajaran bahasa arab (cet : 1 malang :madani 2015),h 137
} 
Arab dan berangkat dari mempelajari kaidah untuk mengajarkan kepiawaian berbahasa Arab tertentu melalui membaca dan menerjemah. Kemudian pembelajaran kaidah nahwu menjadi tujuan akhirnya, karena ia dianggap sebagai sarana untuk mengembangkan kemampuan berfikir. ${ }^{4}$

Metode gramatika dan terjemah ini bukanlah metode baru dalam pembelajaran bahasa Arab, metode ini juga memiliki beberapa nama diantaranya ia disebut dengan metode grammar translation, para guru telah menggunakan metode ini selama beberapa tahun lamanya. Metode ini juga disebut dengan metode klasik, karena disandarkan pada penggunaanyya untuk mengajarkan bahasa-bahasa klasik seperti bahasa latin dan Afrika. Metode ini bertujuan untuk mengajarkan kaidah bahasa peserta didik dan bahasa Arab kepada para peserta didik dengan harapan metode ini bisa membantu mereka untuk mengetahui kaidah bahasa ibu dan aturanaturan bahasa mereka, baik dalam hal berbicara atau menulis. Akhirnya ada keyakinan bahwa mempelajari bahasa Arab itu mengembangkan kemampuan

\footnotetext{
4 Rusydi ahmad thaimah, ta'lim alArabiyah li ghairi al-Nathiqin biha, (Mesir:jami'ah al-manshurah,1989),h 127
}

akal peserta didik, meskipun demikian metode ini selalu menggunakan bahasa peserta didik dalam prakteknya, kecuali jika latihanyya tidak berhubungan dengan akal. $^{5}$

Metode grammar dan translation merupakan hasil karya pemikiran sarjana jerman yang bernama Johan seidenstrucher, karl Plotz, HS Olendorf dan johan meidinger. Metode ini merupakan metode tertua dalam pembelajaran bahasa asing sehingga disebut juga sebagai metode tradisional.

Metode gramatika tarjamah pulalah yang selama ini paling banyak diterapkan dalam kegiatan pembelajaran bahasa Indonesia. Maka tidaklah heran jika para ulama dan cendekiawan muslim di Indonesia mahir membaca kitab kuning atau kitab gundul, namun mereka sangat lemah dalam hal mendengar dan berbicara menggunakan bahasa asing tersebut. Dari semua penjabaran tersebut, dapat dipahami bahwa ciri atau karakteristik metode gramatrika tarjamah adalah sebagai berikut:

\footnotetext{
5 Musa said,Aisyah, Asalib wa mabadi,fi tadris al-lugha, ( Riyadh: jami;ah malik saud 1997),h 11
} 
1. Dalam pembelajaran bahasa, hanya terfokus dengan menghafalkan kaidahkaidah atau tata bahasa.

2. Metode ini mengesampingkan pembelajaran kemahiran bahasa (mendengar dan berbicara), bahkan cenderung dianggap tidak ada.

3. Metode ini lebih mementingkan aspek membaca dan membuang aspek yang lain dalam kemahiran berbahasa.

4. Kalaupun kemahiran bahasa (mendengar dan berbicara) itu diajarkan, namun intensitasnya sangat kecil.

5. Kegiatan pembelajarannya adalah dengan cara memberi contoh-contoh yang kemudian diuraikan berdasarkan kaidah-kaidah gramatika. Atau, biasa juga dimulai dengan mengajarkan kosa kata, kemudian dirangkaikan dengan menjadi sebuah kalimat yang sesuai dengan kaidah gramatika (nahwu dan sharaf) $^{6}$

Dari penjelasan singkat tersebut, maka maetode gramatika tarjamah tidaklah lepas dari kelebihan dan kekurangannya.

6 Ulin Nuha. Metodologi super efektif pembelajaran bahasa arab.(jogyakarta: diva press 2012), h19

\section{a) Kelebihan}

1. Tanpa disadari peserta didik memperoleh pengetahuan dari keduanya (qawaid dan terjemah) dengan pengetahuan yang utuh.

2. Meskipun belum dengan sendirinya peserta didik dapat aktif atau lancar berkomunikasi dengan bahasa Arab, tetapi paling tidak peserta didik dapat berbahasa Arab secara pasif, artinya santri dapat membaca dan menerjamah buku-buku ilmiah yang ditulis dengan bahasa Arab.

3. Cocok untuk digunakan kelaskelas yang memiliki jumlah peserta didik yang banyak.

4. Guru yang tidak fasih bahasa Arab bisa tetap mengajar bahasa Arab dengan menggunakan metode ini

5. Cocok bagi semua tingkatan peserta didik ,baik yang peserta didik pemula,menengah atau peserta didik tingkat atas. Melalui metode ini para peserta didik dapat memperoleh aspek- 
aspek bahasa yang signifikan dengan bantuan buku saja. ${ }^{7}$

\section{b) Kekurangan}

1. Metode gramatika ini mengabaikan skill berbicara yang merupakan skill utama yang seharusnya dipelajari oleh peserta didik ketika belajar bahasa Arab

2. Metode ini banyak menggunakan bahasa peserta didik (bahasa Indonesia) sehingga menjadikan bahasa Arab yang dipelajari sedikit sekali digunakan dalam proses pembelajaran bahasa. Para peserta didik juga tidak mendapatkan waktu yang cukup untuk melatih kemampuan bahasa Arab yang ia pelajari.

3. Metode ini lebih banyak mengajarkan bahasa Arab sebagai ilmu, sehingga dalam proses pembelajarannya metode ini lebih banyak menganalisa kaidahkaidah sebagai bagian dari ilmu bahasa dan tidak mempelajari bahasa sebagai skill untuk berkomunikasi

\footnotetext{
Fathur Rohman, metodologi pembelajaran bahasa arab (cet : 1 malang :madani 2015),h 148
}

4. Metode gramatika ini menghilangkan perbedaan antara peserta didik yang belajar bahasa dengan peserta didik belajar ilmu bahasa, karena tujuan dari metode ini adalah menambah pengetahuan peserta didik tentang bahasa, asal-usulnya, kaidahnya, dan bagaimana cara menerjemahkannya ke dalam bahasa Indonesia.

5. Pembelajaran bahasa Arab biasanya hanya terbatas pada kegiatan guru dan peserta didik didalam kelas saja karena hanya menggunakan kitab. ${ }^{8}$

Dalam kegiatan pembelajaran, seseorang guru harus memperhatikan halhal yang sangat penting, diantaranya ialah sebagai berikut :

1. Penjelasan materinya harus diatur dan disampaikan dengan sederhana serta merta mudah untuk dipahami oleh peserta didik

2. Memulai pelajaran grammar dari tingkat yang paling dasar

3. Penyajian materi haruslah menggunakan contoh-contoh yang 
sederhana dan mudah,agar bisa dipahami. Sebab santri lebih mudah menerima dan memahami grammar jika disampaikan melalui contohcontoh

4. Memperhatikan media pembelajaran, karena waktu cenderung longgar.

5. Guru harus sabar, dalam menjelaskan dan memberikan arahan terhadap peserta didik. Sebab, tidak semua daya serap anak didikiyu sama dan cenderung heterogen. ${ }^{9}$

\section{Implementasi Penggunaan kitab Matan}

\section{Al-Ajurumiyyah di pondok pesantren}

\section{Raudhatul Musthafa Lil Khairaat}

Pondok pesantren Raudhatul Musthafa

Lil Khairaat adalah sebuah lembaga pendidikan yang bertujuan untuk mengembangkan ilmu agama Islam, terutama dalam bidang pendidikan. Pondok tersebut merupakan Pondok Salafiyah yang belajar khusus tentang ilmu agama. Dan Pondok tersebut belajar yang seperti di kutib dalam judul tersebut yaitu belajar tentang bahasa Arab yang

\footnotetext{
${ }^{9}$ Ibid 152
}

tercantum dalam kitab Mat'nu Alajurumiyyah.

Implementasi tersebut meliputi dengan tata cara penjelasan seperti apa yang mereka dapati, dengan cara menggunakan metode yang bisa memahami para santri dan hal yang paling ditekankan dalam pembelajaran ialah bagaimana para santri bisa menghafalkan sebuah matan yang terdapat dalam kitab Al-ajurumiyyah, setelah mereka bisa menghafalkan matan tersebut, mereka para santri ditekankan untuk bisa mengi'robkan sebuah penjelasan dari kitab Mat'nu Alajurumiyyah tersebut. Setelah menghafalkan, baru bisa di jelaskan makna dari kitab Mat'nu Al-ajurumiyyah tersebut, dan ketika mereka para santri sudah bisa menghafalkan, memahami dan mengi'robkan maka mereka bisa naik ke tingkat kitab selanjutnya.

Pembelajaran kitab Mat'nu AlAjurumiyyah di Pondok Pesantren tersebut tidak hanya menggunakan penerapan begitu saja, akan tetapi menggunakan cara 
atau metode yang bisa diterapkan dari ustadz kepada para santri, agar bisa memahami kitab tersebut. Dan untuk memperkuat pendapat di atas mengenai implementasi penggunaan kitab Mat'nu Alajurumiyyah tersebut, penulis juga melakukan wawancara kepada salah seorang santri yang duduk di kelas 2 tsanawiyah yang bernama Faisal Al-Hasni, adapun kutipan wawancara tersebut :

"saya merasa nyaman dan paham ketika ustadz menerapkan cara deduktif dan induktif dalam pembelajaran kitab Mat'nu Al-ajurumiyyah, karena itu sangat membantu kami dalam melaksanakn prosese belajar mengajar, karena dengan cara ini juga kita sabagai santri bisa memahami lebih muda lagi, karena santri dan teman-teman saya lebih banyak dari golongan anak yang kurang faham agama, dan cara ini sangat membantu kami untuk bisa memahami kitab matan juurumiyah tersebut. Dan setelah cara itu kita sudah fahami, kita lebih di tingkatkan dengan menghafal kitab matan tersebut, karena ini merupakan langkah awal kita ketika ingin naik ke jenjang selanjutnya. Pemahaman tentang kitab tersebut mulai dari penghafalan matan, irob dan paling penting itu sering memebaca kitab kuining ketika udah berada dalam tingkatan kitab yang di atas. Dan langsung bisa di praktekkan dan lebih dari itu bisa memberi pemahaman kepada orang lain lewat persentase sebagai bukti dan penguat bahwa si santri tersebut sudah memahami apa yang teelah di ajarkan kepada mereka dan sudah bisa memberikan pemahaman kepada orang lain. Dan target yang paling utama adalah bisa membuat santri bisa meng'irob dan mengetahui makna-makna dan pemahaman setiap pengertian dalam kitab jurumiyah. Dan semua itu tidak lepas dari hafalan." $" 10$

Jadi implementasi yang ada di

Pondok Pesantren tersebut di kembangkan sedemikian rupa agar para santri bisa lebih mengembangkan lagi ilmu yang mereka dapatkan dari ustadz tersebut, karena berbicara tentang kitab Mat'nu Alajurumiyyah ini, tidak bisa dianggap sepeleh, karena ini merupakan kunci awal dari sebuah ilmu untuk bisa memahami kitab-kitab selanjutnya.

Teknik pembelajaran kitab Matan AlAjurumiyyah di pondok pesantren Raudhatul Musthafa Lil khairaat

Berdasarkan hasil observasi dan wawancara, bahwa penggunaan teknik kitab Mat'nu Al-ajurumiyyah diterapkan dikelas 2 tsanawiyah untuk meningkatkan kemampuan pasa santri agar bisa menghafal kitab tersebut agar bisa lanjut ke jenjang kitab selanjutnya.

\footnotetext{
${ }^{10}$ Faisal alhasni, santri Pondok Pesantren Raudhatul Musthafa Lil Khairaat Kota palu, "wawancara", Via WhatsApp (online), tanggal 27 februari 2021
} 
Berdasarkan hasil wawancara penulis bersama ustadz yang mengajar di pondok tersebut beliau mengemukakan bahwa:

"teknik yang biasa di gunakan dalam proses pembelajaran kitab Mat'nu Al-ajurumiyyah di Pondok Pesantren tersebut, menggunakan teknik pengulangan dan latihan." 11

Hasil wawancara penulis dengan narasumber di atas dapat dijelaskan bahwa teknik pengulangan dan latihan ini digunakan untuk memperkuat materi yang diberikan kepada para santri sehingga para santri dapat memahami secara saksama dan mengigat kembali materi yang telah disajikan kepada mereka dari ustadz tersebut. Kemudian ustadz meberikan materi berupa sebuah contoh soal kalimat untuk ditentukan, kalimat-kalimat tersebut ke dalam bentuk isim, fi'il atau huruf, setelah ustadz memberikan tugas mengidentifikasi isim, fi'il atau huruf dari kalimat-kalimat yang disajikan. Dan setelah para santri bisa memahami contoh-contoh tersebut,

${ }^{11}$ Faturahman, ustadz Pondok Pesantren Raudhatul Musthafa Lil Khairaat Kota palu, "wawancara", Via WhatsApp (online), tanggal 5 februari 2021 ustadz mengajak kepada para santri untuk mengidentifikasi isim, Fi'il atau huruf yang terdapat dalam pembelajaran kitab Mat'nu Al-ajurumiyyah. Penekanan ini dilakukan untuk meningkatkan kemampuan memahani bagian-bagian dari pembelajaran kitab Mat'nu Alajurumiyyah. Penggunaan kitab Mat'nu Al-ajurumiyyah terhadap para santri mempunyai pengaruh yang baik dan signifikan.

Hal itu terbukti sesuai dengan pernyataan yang dikemukakan salah satu santri kelas 2 tsanawiyah, beliau mengatakan bahwa :

“ Menurut saya teknik pembelajaran dalam proses belajar mengajara yang terdapat dalam kitab Mat'nu Alajurumiyyah sangat membantu kami dalam memahami dasar-dasar kitab Mat'nu Al-ajurumiyyah dalam menentukan isim, fi 'il, atau huruf. ${ }^{12}$

Jadi penggunaan teknik Matan AlAjurumiyyah sangat penting untuk meningkatkan pemahaman para santri guna meningkatkan kemampuan dasar pembelajaran bahasa Arab.

${ }^{12}$ Faisal alhasni, santri Pondok Pesantren Raudhatul Musthafa Lil Khairaat Kota palu, "wawancara", Via WhatsApp (online), tanggal 27 februari 2021 
Kendala dan solusi penggunaan teknik penggunaan Kitab Matan AlAjurumiyyah di Pondok Pesantren Raudhatul Musthafa Lil khairaat.

Berdasarkan hasil obervasi dan

wawancara penulis di lokasi penelitian

tersebut, mengenai penggunaan teknik

Mat'nu Al-Ajurumiyyah terdapat beberapa

kendala yang harus dihadapi serta solusi yang ditempuh sebagaimana yang telah disampaikan oleh salah satu ustadz sebagai berikut.

"Ada beberapa kendala dalam penggunaan kitab Mat'nu Alajurumiyyah dalam prosese pembelajaran bahasa Arab di Pondok Pesantren Raudhatul Musthafa Lil Khairaat, antara lain :

a. Ada beberapa santri yang masih belum mampu mengucapkan beberapa huruf hijaiyah (al fabet) sesuai dengan makhra'rijul huruf (tempat keluarnya huruf yang benar.

b. Ada beberapa santri yang masih belum lancar membaca tulisan yang berbahasa Arab, sehingga tentunya mereka merasa kesulitan dan juga belum lancar membaca kitab Mat'nu Al-ajurumiyyah yang menggunakan bahasa Arab sebagai bahasa pengantar.

c. Terkadang para santri merasa jenuh apabila terus-menerus mempelajari bahasa Arab secara monoton. ${ }^{13}$

${ }^{13}$ Faturahman, ustadz Pondok Pesantren Raudhatul Musthafa Lil Khairaat Kota palu, "wawancara", Via WhatsApp (online), tanggal 5 februari 2021
Kendala penggunaan kitab Mat'nu Alajurumiyyah ini salah satunya ialah materinya yang sederhana yang membuat orang mempelajari bahasa Arab harus banyak menambah reverensi yang ada untuk melengkapi kekurangan-kekurangan yang ada. Sementara keadaan para santri membutuhkan bimbingan dan pengajaran dari para ustadz yang khusuh objek kajiannya ke kitab Mat'nu Al-ajurumiyyah. Karena kitab Mat'nu Al-ajurumiyyah ini memiliki sub bab atau isi yang harus benar-benar di mengerti dan di pahami. Makanya ada perlu yang namanya pengulangan pembelajaran tersebut. Di samping itu juga ada sebagian para santri yang dari golongan yang tidak paham akan materi ini, lambat laun mereka akan bisa memahami lagi.

Adapun solusi yang bisa ditawarkan dalam pembelajaran kitab bahasa Arab lebih khusus ke kitab Mat'nu Alajurumiyyah kepada para santri yang masih mengalami banyak kendala dalam membaca huruf hijaiyah (alfabet) perlu 
diberikan bimbingan khusus untuk meningkatkan kemampuan membaca sehingga mempermudah para santri untuk memahami kitab Mat'nu Al-ajurumiyyah, hal ini senada dengan perkataan narasumber sebagai berikut :

“ 1. Bagi para santri yang belum mampu mengucapkan beberapa huruf hijaiyah (al-fabet) sesuai dengan makhra'rijul huruf (tempat keluarnya huruf) yang benar dan belum lancar membaca tulisan berbahasa Arab, maka para ustadz memeberikan sebuah dorongan atau motivasi kepada para santri untuk terus berlatih membaca tulisan berbahasa Arab, terutama yang terdapat dalam kitab Matan alajurumiyyah. Disamping itu juga para ustadz memberikan tugas-tugas individu kepada para santri agar dapat meningkatkan kemampuan para santri di dalam menguasai bahasa Arab. 2. Jika para santri merasa jenuh akan hal semua ini, maka ustadz menyelingi pembelajaran tersebut dengan kegiatan lu'bah lughawiyah (permainan bahasa) yang sesuai dengan materi pembelajaran."14

Berdasarkan hasil wawancara dari narasumber tersebut, ada beberapa solusi yang di tawarkan dalam pembelajaran bahasa Arab terutama bagi para santri yang belum mampu membaca beberapa huruf hijaiyah (tempat keluarnya huruf) sesuai

\footnotetext{
${ }^{14}$ Faturahman, ustadz Pondok Pesantren Raudhatul Musthafa Lil Khairaat Kota palu, "wawancara", Via WhatsApp (online), tanggal 5 februari 2021
}

dengan makha'rijul huruf (tempat keluarnya huruf) yang benar dan tepat, maka seorang ustadz harus memberikan sebuah motivasi dan bimbingan secara khusus serta menyelingi pembelajaran bahasa Arab.

Dalam pembelajaran kitab matan al-ajurumiyyah ini masih tepat penggunaan nya sesuai dengan ringkat pemahaman para santri. Sebagaimana yang di sampaikan oleh salah satu santri kelas 2 tsanawiyah sebagai berikut.

"Menurut saya, sampai saat sekarang ini
penggunaan kitab matan al-ajurumiyyah
masih tepat untuk digunakan. Sebab
melihat sitausi dan kondisi tentang
tingkat pemahaman dalm pembelajaran
bahasa Arab yang begitu rendah,
karena dalam kitab matan al
ajurumiyyah ini sangat begitu penting.
Akan tetapi, bukan sesuatu yang salah
apabila kita ingin menganjak ke kitab
yang selanjutnya untuk memahami
lebih dalam lagi. 15
Dari penjelasan di atas, sangatlah jelas bahwa pembelajaran bahasa Arab di pondok pesantren Raudhatul Musthafa Lil khairaat kota palu selama ini tepat untuk

\footnotetext{
15 Faisal alhasni, santri Pondok Pesantren Raudhatul Musthafa Lil Khairaat Kota palu, "wawancara", Via WhatsApp (online), tanggal 27 februari 2021
} 
digunakana. Dan dikuatkan dengan

pendapat seorang santri, dengan

mengungkapkan:

"Sampai kapanpun kitab Matan Alajurumiyyah masih tepat untuk digunakan. Karena memang kitab Matan Al-ajurumiyyah ini merupakan sebuah dasar untuk melanjutkan pembelajaran bahasa Arab. Dan untuk menaiki kitab selanjutnya, harus bisa menguasai kitab matan Al-Ajurumiyyah seperti kitab Muktasar Jiddan, Kafrawi, dan Kawakib dan kita yang tinngi lainnya. Oleh karena itu, kitab Matan Al-ajurumiyyah bisa di gunakan saat ini sampai waktu yang tidak terbatas". ${ }^{16}$

Itulah penjelasan singkat dari salah seorang santri tentang teknik penggunaan kitab Mat'nu Al-ajurumiyyah yang sampai saat ini masih tepat digunakan, bahkan pembelajaran kitab matan al-ajurumiyyah ini juga dipelajari sesuai dengan tingkat pemahaman para santri. Seperti yang di ungkapkan oleh seorang santri. Dia mengemukakan bahwa:

"pembelajaran bahasa Arab dengan menggunakan kitab matan alajurumiyyah sangatlah sesuai sebab kitab matan al-ajurumiyyah ini merupakan tingkat dasar dalam mempelajari bahasa Arab, sesuai dengan kondisi dan keadaan yang ada.

16 Surya lubis, santri Pondok Pesantren Raudhatul Musthafa Lil Khairaat Kota palu, "wawancara", Via WhatsApp (online), tanggal 28 februari 2021
Khususnya saya, saya masih orang pemula dalam mempelajari ilmu ini. Olehnya itu, sampai kapan pun tidak akan pernah lepas dengan kitab matan al-ajurumiyyah. Dan kitab ini nkita gunakan dalam metode gramatika tarjamah bersama ustadz-ustadz kami." 17

Dalam pembelajaran kitab matan al-ajurumiyyah alangkah baiknya digunakan metode gramatika tarjamah agar pemahaman para santri dalam mempelajari kitab matan al-ajurumiyyah cepat dipahami. Namun, dalam penggunaan metode tersebut, semua metode terdapat dalam buku yang ada memiliki kelebihan dan kekurangannya masing-masing. Adapun kelebihan dan kekurangan dalam metode gramatika tarjamah. Sebagaimana yang disampaikan langsung oleh ustadz yang mengajarkan, beliau mengemukakan bahwa:

"Metode gramatika tarjamah ini yang di terapkan di pondok pesantren Raudhatul Musthafa Lil Khairaat kota palu memiliki kelebihan yaitu para santri dapat paham dan mengerti akan materi yang di ajarkan dan para santri juga menafsirkan dua bahasa yaitu bahasa Arab dan bahasa Indonesia. Sedangkan kelemahannya ialah para

${ }^{17}$ Faisal alhasni, santri Pondok Pesantren Raudhatul Musthafa Lil Khairaat Kota palu, "wawancara", Via WhatsApp (online), tanggal 27 februari 2021 
santri harus memadukan berbahasa indonesianya dan bahasa Arabnya. Dan memerlukan waktu yang lama, memerlukan kesabaran, ketekunan, kerajinan dan kedisiplinan." 18

Dari kesimpulan yang bisa diuraikan di atas ialah yang menjadi kelebihan dan kelemahan metode gramatika tarjamah adalah menjadikan para santri mampu memahami materi kitab matan alajurumiyyah mengingat materinya begitu singkat, padat dan jelas. Begitupun dengan metode ini, para santri bisa bercakap dengan mudah karena adanya pembiasan dari para ustadz yang mengajarkan tentang metode ini.

\section{DAFTAR PUSTAKA}

Anwar, Moch: ilmu sharaf, terjemahan matan kailani dan nazham al maqsud, Bandung: penerbit sinar baru algensindo offset, 2018

Al-fathi, Ba'bud thulab: ilmu nahwu syarah kitab Al-Ahurumiyyah. temboro magetan jawa timur: barokah, 2012.

Ahmad, Thaimah, rusydi ta'lim alArabiyah li ghairi al-Nathiqin biha. Mesir: jami'ah al-manshurah,1989.

Asy-Syurbasi a hmad, Sejarah dan Biografi Empat Imam Mazhab Hanafi, Maliki, Syafi'I Hambali, (Jakarta: PT. Bumi Aksara, 1993), 168.

18 Faturahman, ustadz Pondok Pesantren Raudhatul Musthafa Lil Khairaat Kota palu, "wawancara", Via WhatsApp (online), tanggal 5 februari 2021
Aisyah, Musa said: Asalib wa mabadi,fi tadris al-lugh., Riyadh: jami;ah malik saud 1997.

Alhasni, fausal : santri Pondok Pesantren Raudhatul Musthafa Lil Khairaat Kota palu, "wawancara", Via WhatsApp (online), tanggal 27 februari 2021

Departemen Agama Ri, Al-Qur'an dan Terjemahannya, Surabaya: Alhidayah.1998

Dayyab, Hifni: Kaidah tata bahasa arab. Jakarta: Darul ulum Press, 1986.

Darwis, Amri: Metode Penelitian Pendidikan Islam. Jakarta: PT Raja Grafindo Persada, 2014.

Fauzi Ilham, Model pembelajaran kitab Aljurumiyah di pondok pesantren wali songo desa sukajadi kecamatan bumiratun nuban lampung tengah, skripsi, jurusan pendidikan agama islam, fakultas tarbiah Universitas islam negeri (IAIN) Metro. 2017

Fuad, Effendi ahmad: metodologi pemebejalaran bahasa arab, Malang: Miskat,2005.

Faisal, Sampiah: penelitian kualitatif: dasar-dasar dan aplikasi, Malang: Yayasan Asih Asah Asuh, 1990.

Faturahman, ustadz Pondok Pesantren Raudhatul Musthafa Lil Khairaat Kota palu, "wawancara", Via WhatsApp (online), tanggal 5 februari 2021

Hasbullah, Dasar-dasar ilmu pendidikan, Cet. X; Jakarta: Raja Grafindo persada, 2012.

Ilmuan islam, ilmu nahwu (on-line ) ( https://id.m.wikipedia.org), di akses pada tanggal 20 september 2020

Margono, S: Metode penelitian pendidikan, Cet. I ; Jakarta: Rineka cipta, 159 
Iqbal, M: Pokok-pokok metodologi penelitian dan aplikasi, jakarta: gralia indonesia, 2002.

Lubis, Lubis: santri Pondok Pesantren Raudhatul Musthafa Lil Khairaat Kota palu, "wawancara", Via WhatsApp (online), tanggal 28 februari 2021

Nasution, Metode Research (Penelitian Ilmiah), Cet. IV; Jakarta: Bumi Aksara, 2004.

Nuha, Ulin: Metodologi super efektif pembelajaran bahasa arab, Jogyakarta: diva press, 2012.

Purmana, reza: pembuat aplikasi kitab aljurumiyah tiga bahasa menggunakan algoritma heap dan metode bind service essential, skripsi jurusan teknik informatika, fakultas sains dan teknologi, universitas islam negeri sunan gunung Djati bandung. 2016

Ruslan, Rosady: Metode penelitian; public relations dan komunikasi, Jakarta: PT Raja Grafindo persada, 2008.

Rohman, Fathur, metodologi pembelajaran bahasa arab, Cet. 1; Malang madani, 2015.

Seorang kyai., Biografi imam ibnu ajjurum pengarang kitab "jurumiyah" (on line), (https://blogspot.com), diakses pada tanggal 18 september 2020.

Suprihatiningrum, Jamil strategi pembelajaran: Teori dan praktik, Jogyakarta: Arruz media, 2013.

Suharsaputra, Uhar Metode penelitian kuantitatif, kualitatif, dan tindakan, Cet II; Bandung :PT Refika Aditama, 181.

Syah, Darwyn, perencanaan system pengajaran pendidikan agama islam, Jakarta: Gaung persada pers, 2007.

Sugiyono, Metode Penelitian Administrasi, Bandung: Alfabeta, 2007.

Tuanku, Khatib Ramayulis: filsafat pendidikan islam, Cet IV; Jakarta pusat: penerbit kalam mulia, 2015.

Takiyyatud, Dinalawiy: Manaqib Imam Ash shinhajiy pengarang kitab alajurumiyah fi nahwi (on-line), (https://blogspot.com), di akses pada tanggal 15 september 2020

Yasyin, Sulchan: Kamus lengkap bahasa Indonesia, Cet ; 27 Surabaya: Amanah, 1997.

Zainal: Pimpinan Pondok Pesantren Raudhatul Musthafa Lil Khairaat Kota palu, "wawancara", Via WhatsApp (online), tanggal 19 januari 2021. 
Al Bariq : Jurnal Pendidikan Bahasa Arab, 2, (1), 2021, 29-44 